Int. J. Electrochem. Sci., 11 (2016) $9941-9948$

\title{
Electrochemical Performance study of Metal ions co-doping in B-site of LTO Anode Material
}

\author{
Li-ge Wang ${ }^{*}$, Fuyun Li, Min Zeng
}

School of Materials Science and Engineering, Southwest University of Science and Technology, Mianyang 621010, P R China

E-mail: wanglige@swust.edu.cn

doi: $10.20964 / 2016.12 .23$

Received: 22 August 2016 / Accepted: 2 October 2016 / Published: 10 November 2016

Metal ions co-doped $\mathrm{Li}_{4} \mathrm{Sb}_{\mathrm{x}} \mathrm{Cr}_{\mathrm{x}} \mathrm{Ti}_{5-2 \mathrm{x}} \mathrm{O}_{12}(0 \leq \mathrm{x} \leq 0.1)$ anode material had been successfully synthesized by solid state reaction method. The electrochemical properties of these spinel anode materials had been investigated. The results showed that $\mathrm{Li}_{4} \mathrm{Sb}_{\mathrm{x}} \mathrm{Cr}_{\mathrm{x}} \mathrm{Ti}_{5-2 \mathrm{x}} \mathrm{O}_{12}$ materials with good crystallization and the metal ions $\mathrm{Sb}^{5+} / \mathrm{Cr}^{3+}$ had entered the $\mathrm{Ti}^{4+} \mathrm{B}$-site lattice without destroying or changing the crystal structure of $\mathrm{Li}_{4} \mathrm{Ti}_{5} \mathrm{O}_{12}$. Compared with pristine $\mathrm{Li}_{4} \mathrm{Ti}_{5} \mathrm{O}_{12}$ anode material, the $\mathrm{Li}_{4} \mathrm{Sb}_{0.05} \mathrm{Cr}_{0.05} \mathrm{Ti}_{4.9} \mathrm{O}_{12}$ materials presented the best charge/discharge capacity, better reversibility and higher cyclic stability, especially at high current rates, for lithium-ion batteries.

Keywords: Metal ions co-doping, $\mathrm{Li}_{4} \mathrm{Sb}_{\mathrm{x}} \mathrm{Cr}_{\mathrm{x}} \mathrm{Ti}_{5-2 \mathrm{x}} \mathrm{O}_{12}$, Anode material, lithium storage capacity

\section{$\underline{\text { FULL TEXT }}$}

(C) 2016 The Authors. Published by ESG (www.electrochemsci.org). This article is an open access article distributed under the terms and conditions of the Creative Commons Attribution license (http://creativecommons.org/licenses/by/4.0/). 